\title{
THE INTRODUCTION OF HR KNOWLEDGE EXCHANGE SYSTEM AND EXPERT NETWORK IN HUNGARIAN CIVIL SERVICE TO SUPPORT THE REORGANISATION OF PERSONNEL MANAGEMENT ${ }^{1}$
}

\author{
Zoltán Hazafi ${ }^{2}$ and Nikolett Pintér ${ }^{3}$
}

DOI: 10.24989/ocg.v.338.5

\begin{abstract}
The development of the Hungarian Public Administration's personnel management has been deeply impacted by the on-going global reinterpretation of the general role and significance of HR in government departments, and by the simultaneous paradigm shift in civil service.
\end{abstract}

Meaning, that on the one hand Human Resources Management has become a strategic partner to leadership in human-oriented organisational development. It is able to aid the interpretation of challenges and the aim of policy reforms, planning, execution and evaluation of changes, impact assessment and reporting.

On the other hand, organisational decision-making has been gaining significance, while at the same time, the centralized legal regulation has become less relevant in HRM does questions due to the deregulation of human resources management in civil service.. This tendency puts a higher emphasis on HR Knowledge Exchange Systems and knowledge-sharing methods.

The HR Knowledge Exchange System and Expert Network plans with the aim of providing online and offline support to HR professionals in public administration in order to improve their HR knowledge and competencies of both offline (project-based events) and online (via Online Forum) professional communities.

Combined, the HR Knowledge Exchange System and Expert Network provides support to HR professionals primarily through granting access to an online academic research database with upto-date content, forum discussions as well as face-to-face counselling in a way that fits the requirements of the current tendencies of the reorganisation process of HR functions. It also contributes to the implementation of the 'Healthy Organisation Model' in practice.

\footnotetext{
${ }^{1}$ In order to prepare this paper we would like to thank Bernadett Kiss (Head of Personnel Development and Services Department in Hungarian Ministry of Interior) and Balázs Kosztra (managing partner of Concordia Ltd) for their professional support, and Eszter Szabados (Employee of Personnel Development and Services Department in the Hungarian Ministry of Interior) for proofreading in English.

${ }^{2}$ Associate professor, National University of Public Service, Hungary

${ }^{3} \mathrm{PhD}$ student, Doctoral School of Public Administration Sciences, National University of Public Service, Hungary
} 


\section{The Effects of Paradigm Shifts In Human Resources Activities In The Hungarian Government Administration}

Two trends will determine the human resources activities of the Hungarian government administration over the next few years. One of these trends is the digital transformation, which creates the opportunity for human resources management to become a strategic player, and the other one is the decentralization and deregulation of the government HR management. The former is a global process that affects all sectors in general, while the latter one is a change determined by national characteristics and specific to government administration only. Nonetheless, both focus on innovation development and HR knowledge-sharing, which play a vital role in the successful transformation of HR.

\subsection{The Impact of Digital Transformation On HR Function}

\subsubsection{Business sector}

There is a global tendency to redefine the place and role of the human resource function in order to better support the adaptation of companies to changes in the market, technology, and social environment. While it is evident that the continuously changing environment means a challenge to $\mathrm{HR}$, the latest on-going changes are quite irregular as they are more complex and faster than ever, profound and constant; they are continually forcing HR professionals to think in a broader, strategic way and to introduce new methods. Under these circumstances, companies will be able to remain competitive only if they can keep up with the pace of changes and also adapt their employee development to these changes.

In the next few years, the Fourth Industrial Revolution (Industry 4.0) will bring about the most significant changes in the life of companies. It forces them to rethink their human resources situation. It is enough to refer only to that, thanks to technological advances, nearly $40 \%$ of routine tasks will be able to be automated (cf. [1], p. 10). At the same time, work processes become more complex, and the importance of interpersonal or personal skills (commitment, responsibility, communication, etc.) grows. Within five years, most of the top 10 most sought-after competencies will consist of the socalled soft competencies - analytical skills, creativity, emotional intelligence ([1]. p. 12) - while critical thinking and problem solving also come to the fore [2].

Besides the cloud-based solutions of well-known major generic HR information systems - SAP, Oracle, or Workday - nowadays, there are solutions specifically designed to support specific HR activities. The Clustree is a French development purely based on artificial intelligence, with modules that offers a complex solution to HR challenges. [3]

The question arises on how the digital revolution affects the future of the HR function. The attention focused on personal characteristics, behaviour, and their analysis in itself values the HR activities. It has become apparent that their development can bring about a competitive market advantage, which further strengthens HR activities that focus on the individual needs of employees.

The major obstacle to digital transformation is the limited availability of human capacity for digital transformation. [4] Predictably it will become even more challenging to acquire and retain the talent in the future. It is no coincidence that competing for talent is considered the greatest challenge of the near future. At the same time, there will be an increasing demand from companies for employees with the competencies needed for digital transformation. This means not only the technical competencies 
had to apply digital tools but also the skills had to manage the changes. To fill the gap, HR, besides traditional methods like internal mobility, alternative employment, has to apply new technological tools, increasing the efficiency of recruitment and selection. [5]

The HR function also needs to be prepared for the change in the learning process. Positions are to be terminated; new ones are to be created or transformed. Changes are rapid and require new competencies that will be more and more difficult to obtain from outside, from the labour market. Managing the impact of digital transformation on work environment and competencies is an essential requirement for preparing for the future. (cf. [2], pp. 43-46)

In response to accelerated changes, three trends in learning are emerging: work-based learning is becoming more emphasized, the acquisition of knowledge is getting more personalized, and the lifelong-learning model will be implemented soon. (cf. [5], p.7.)

As mentioned, internal mobility becomes a decisive means for satisfying the need for change and new competencies. Changing positions, being moved within the company is becoming general, a natural part of the career. The new technologies facilitate internal mobility. All of this creates another challenge for HR.

The organisational development for digital transformation cannot be achieved without staff support. Management needs the HR expertise that enables them to foresee the future impact of changes and to respond strategically on the field of human resources. It brings to the fore the strategic planning of human resources, as well as the data- and fact-based HR strategic decisions, and the cloud-based IT solutions that serve them. To achieve this, HR professionals must learn data analysis, statistical methods, and techniques. Furthermore, it needs to build the trust of management regarding the credibility of HR analyses and forecasts. The change is getting outlined. Companies treat the development of HR data analysis capabilities as a development priority over the next few years.

Forecasts count the HR profession among the winners of the digital transformation. (cf. [1], p. 9) This also means the realization of the long-proclaimed vision of the HR profession to become a strategic partner for the management.

However, HR only will be able to meet these above-mentioned challenges if it has the knowledge to transform, owns the new methods and techniques. At the same time, it is clear that as era shifts, old knowledge, methods, and procedures become obsolete, so they cannot be used under the changed circumstances, but new HR knowledge and experience are not yet available. Under these circumstances, innovation, the development of HR knowledge, the establishment of expert collaborations and networks are getting more appreciated.

\subsubsection{Public Sector}

E-government primarily means having the public services available on a digital platform. Besides enhancing the efficiency of operational processes, digital developments are ultimately aimed at fulfilling the needs of internal and external customers. (Private and public citizens, (cf. [6], p. 99) Egovernment is not only a vital part of public service development, but it derives the entire sector by inducing more dynamic and thorough changes and improves on an additional area of organisational development in some cases. (ibid.) 
At the same time, we cannot deny the fact that digitalization is taking over the public sector at a rather moderate pace. In general, there are significant digital improvements in HR functions such as recruitment, selection, internal mobility, and training management, but there is less capacity to assess the results of digitalization. The initiative of the Canadian government to create a work environment focuses on the organisational activities (milieu de travail axés sur l'activité) is one of the exceptions as it considers the impacts of digitalization as well. [7]

Dutch public service uses digital tools also for marketing purposes. The digital platform of werkvoornederland serves as a development tool for job branding, which not only enlists the current vacancies but sells them at the same time. [8] Each position is linked to a career development path, implying the potential projects and additional assignments it might entail. The applicants can also obtain further information on the flexibility of the job and future career opportunities. According to user statistics, these factors are the most frequently considered ones by the candidates. [9]

The recruitment and selection procedures of the British Government Recruitment Service are entirely automatized. The employer and the candidate can check the current status of the application process. [10]

In Austria, a job catalogue was created to support the internal mobility of the federal public service and help employees seeking career development by switching to higher or different positions. (Mobilitätsmanagement) In addition to that, the system contributes to reaching the optimal staffing level. [11]

In France, an online market place was introduced to the citizens in order to maintain sufficient planning of the available budget for training and professional development support. The application (Monocompteformation) is built upon the concept of the latest service distributing trends (like Airbnb for example), [12] the users have their accounts and they can browse for training courses fulfilling their career development needs. Based on the research criteria, the system ranks the courses by ratings and reviews received from other users. If the ratings match, the system generates a random order. Users can apply for the selected training through the application. There are over a million of courses being managed with the help of the application software on an annual basis.

Information security risk management has become the centre of attention in Germany as a primary development area. The respective ministry and two public-sector trade unions are about to seal a collective agreement, concerning the question of information security among many others. [13]

Generally speaking, it might be said that there are on-going updates of HR processes, methods, and techniques that are to be tested and implemented simultaneously with the recent technological developments.

Considering the increasing popularity of the remote working style, the federal government of the United States has recently created a website for sharing reports, studies on the subject, as well as related online courses, activity, and legal guidelines. It also provides a platform for employers and public servants to discuss their questions related to remote work. [14]

In Latvia, an innovation lab was launched, called GovLabLatvia, to strengthen innovation culture and support organisation development projects related to public service HRM reforms. The concept aims to motivate and nurture multidisciplinary partnerships and workgroups offering complex solutions. The workshops develop HR prototype methods in a 'laboratory' environment that are suitable for 
testing. By the end of 2019 already 50 workshops have been active with 150 participants and developed 16 prototypes in total. [15]

\subsection{The Impact of Decentralization and Deregulation on Human Resource Management}

The Hungarian government administration has been facing with decreasing market appeal, high staff fluctuation, and low performance and internal mobility for years.

In order to tackle the system-level issues mentioned above, the legal status of government employees has been revised radically. The revised law (Kit.) has shifted from a career-based personnel system towards a more flexible and open-minded policy approach, which lays significant emphasis on deregulation and decentralization.

In several aspects, the Kit has abolished policy formulation and implementation on a legislative level and integrated the decision making and policy creation process into the employer's scope of activities. For instance, it has eliminated career advancement and fixed salary based on seniority and the length of employment, which were being regulated by the law, and implemented a performance-based compensation system, offering competitive salaries that are aligned with the market standards.

The paygrade is determined by the employer, based on the educational level, personal attributes, and performance of the employee between a wider pay-range. The employer holds the right to decide on the determining factors of the salary structure, which can vary by the local peculiarities.

The educational requirements of employment are also determined without any legal constraints by employers in a decentralized manner.

Due to the deregulation and decentralization, the scope of the employer has been extended which made it possible to endorse the local peculiarities. On the other hand, decentralization also means each unit has a different set of policies in place.

Deregulation and decentralization itself do not add value, by leaving more room for flexibility; it only offers the opportunity to increase the performance of the organisation. Thus Human Resources Management has to adjust to the paradigm shift in policy formulation in order to truly leverage on that.

The status of government officials, terms and conditions of employment used to be regulated by the law, meaning that each of the HR processes used to be established within a standard legal framework and the main key performance indicator of the HR activities was the level of accuracy how the legal requirements are served in terms of execution and operation.

As opposed to the old paradigm, the new one draws upon the current state of affairs of the private sector. The legal framework only impacts the human resource management of the organisations, and the specific rules are determined by internal guides or different codes of conducts. [16] These guides and code of conduct can be held accountable from a legal point of view, in case of breaching the code, employees can be dismissed, and legal arguments can be initiated against the employer.

In a changing legal environment, organisations autonomously develop their HR processes, e.g., recruitment, selection, promotion, remuneration, assessment, development, etc. This is not only an option but also a constraint, as in the absence of previous legal norms, human resources management 
would remain unregulated. Management must adapt to changed circumstances, and adaptation requires a new leadership culture. Only those who are against the tradition tradition, have a different view of $\mathrm{HR}$ and require personnel support in at least the following areas, can enjoy the greater freedom of decision provided by law:

- $\quad$ HR expert consultation (legal expertise, knowledge of the legislation, monitoring compliance with legal frameworks)

- Talent and competency development (activities promoting/assisting the versatility of government officials, competence and talent development)

- $\quad$ Change management (promoting acceptance of change, raising awareness of decision-makers' responsibility)

- $\quad$ Innovation and proposals (designing new work platform, model experiment)

- $\quad$ Strategic partnership (participation in strategic decision making, sensitization of leadership teams to HR challenges, management of social dialogue)

At the same time, the essence of personnel knowledge is also changing. Personnel professionals are expected to be aware of legal provisions, understand talent selection, be able to assess and develop competencies, support the adoption of organisational changes, propose new work frames, conduct model experiments, engage in strategic decision making, and social dialogue.

\section{The „HR Knowledge Exchange System and Expert Network” project as an online and offline HR social network}

In Hungary, the Civil Service's human resources system is extremely diverse, including three different parts of Hungarian Civil Service (Public Administration, Police, Military). The application of specific, various employment rules of different parts of Hungarian Civil Service requires wellprepared, highly qualified HR professionals with up-to-date knowledge from different fields. The various employment regulations within the Hungarian Civil Service necessarily requires the need to ensure access to a summarized human resources knowledge in one place for all HR professionals in all organisations of Hungarian Civil Service.

Currently the theoretical and practical HR knowledge is not equally available to all HR professionals and HR leaders in three parts of Hungarian Civil Service. In addition they have no social network, they have no opportunity to share best practises with each other, they currently need to solve difficulties and problems individually and the solutions remain at separate organisational level and there are no trustworthy and widely known professional solutions to solve the organisational problems. Moreover there is no specific HR system for the HR departments of Hungarian Civil Service that would collect, organize and provide HR related knowledge and access for all HR professionals and HR leaders [17]. At the same time, in the period of digital transformation and in the age of growth of employer HR competencies Hungarian Civil Service is in the need of a system to share the theoretical and practical HR knowledge for their HR departments. That is why the Hungarian Ministry of Interior's aims to establish the „HR Knowledge Exchange System and Expert Network" project for HR professionals and every employee in all part of Hungarian Civil Service.

HR Knowledge Exchange System and Expert Network offers to HR professionals and their leaders of Hungarian Civil Service online and offline organisational-fit support in HR related fields according to adequate part of Civil Service and online and offline HR social network. 
The member of Expert Network (called Experts) do compiling, preparing and keeping HR knowledge up to date, they have outstanding professional knowledge and experience in the field of HR. Their task is to produce professional publications, to respond within the Online Forum, to ensure organisation-fit recommendations to the HR professionals and their leaders in offline or online ways. The Experts support the HR professionals and their leaders to make their work more efficient and to make themselves more effective by working in HR departments. Through the Online Forum they can provide continuous professional advice to the HR departments. Beside to the Experts are the members of Censorious Committee. They are responsible for determining which knowledge can reach the target group by approving papers from Experts. They supervise that the HR Knowledge Exchange System and Expert Network offers trustworthy, up-to-date, high standard knowledge to the HR professionals and their leaders.

HR Knowledge repository portal ensures up-to-date knowledge in the following HR related fields: [17]

Legislation on HR activity, HR law enforcement

Creating job descriptions - analysis, evaluation

Recruitment, selection

Achievement Evaluation System

Employee- development, career planning

Compensation, rewards

Personnel issues

Labour relations - advocacy

Organisational culture

HR Knowledge repository portal has two sections: 1, Online Forum and 2, Knowledge thesaurus. HR professionals and their leaders may ask questions from the Experts, Experts can give recommendations online. All users can share best practises and their experience with each other. Knowledge thesaurus is open for Experts to upload papers after the approval of Censorious Committee. Universities may also upload academic publications.

The groups of HR Knowledge Exchange System and Expert Network (HR professionals, member of Expert Network and of Censorious Committee) can take part at online-organized and offline events to enlarge or share their theoretical and practical HR knowledge. 


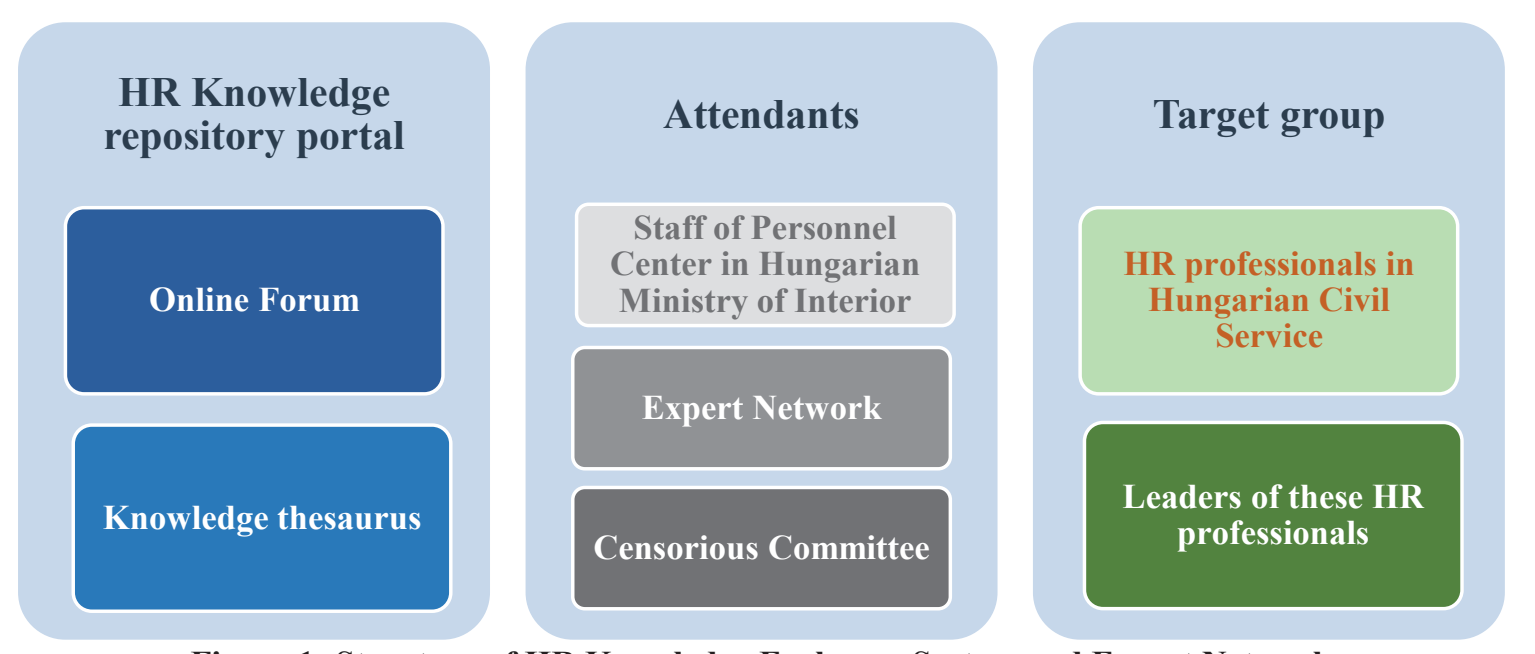

Figure 1: Structure of HR Knowledge Exchange System and Expert Network Source: Authors

\section{Introduction of the Healthy Organisation model}

According to Lövey and Nadkarni's definition, an organisation can be considered healthy if the following statements characterize its functionality: (cf. [18], pp. 42-45)

- A healthy organisation satisfies customer needs by providing great value for the customer. Thus it earns legitimacy for its existence and the ability to maintain the organisation as a going concern via the continuous stream of revenues,

- A healthy organisation satisfies the needs of its members by creating an environment where members develop (grow) and believe that they matter, and so they can fulfil their individual objectives while they realize the objectives of the organisation,

- A healthy organisation satisfies economic requirements (financial benchmarks such as profitability imposed mainly by markets and regulators) by using resources most efficiently and effectively in its pursuit of objectives,

- A healthy organisation maintains a balance between these three fundamental objectives by developing a structure and a culture that encourage, considering all three simultaneously when making decisions,

- A healthy organisation lives in harmony with its natural social and economic environment.

- A healthy organisation grows and develops over time, increasing its reach and/or ability to handle complex situations.

Lövey et al. define organisational health as the holistic condition of these six main health criteria being satisfied to a high degree concurrently. [18]

Naturally, satisfying these is not a binary, yes no, choice but a question of degree. The objective of an attempted , assessment ${ }^{\mathrm{e}}$ is not the identification of this degree to minute detail; instead it is to indicate what may need to be addressed in order to build a healthier organisation.

When the problem-solving mechanisms are absent, weakened, or slow in response, problems occur, persist, or recur, wasting energy and resources in a preoccupation with short-term and partial remedies, not main purposes. This phenomenon is called organisational disease. The organisational diseases are those situations in which part(s) of the organisation do not fulfil their functions further 
to the requirements, some of the organisation's processes persistently fail to meet requirements, and one or more of the fundamental objectives are repeatedly neglected in the decision-making process.

In order to understand the state of health of an organisation, must to mention and compare the identified symptoms of ill-health to a typology of organisational diseases in the absence of which the diagnosis of the state of health becomes a random collection of information. Typology associates the disease with the following: [18]

- the part of the organisation where the malfunction is located,

- the location where the effect of malfunction is mainly felt, or

- the structures and systems that tend to perpetuate the problem.

If the organisation is oblivious to these problems, they become acute. Acute problems radiate outward to related areas of operations, decreasing functionality exponentially.

As problems become recurrent, typical behaviour manifests in organisations. These are observable behaviour patterns associated with problems, symptoms. Our diagnosis of organisational health consists of observing the various symptoms and classifying them similarly to diseases of the human body. Symptoms of organisational diseases must appear together to constitute the disease.

Diagnosis of organisational health entails a focused collection of data for the purpose of identifying and treating organisational diseases. To treat a disease, after ascertaining the nature of it, one must determine its cause. To be able to state that a cause renders an organisational disease, it must be noticed that whenever the cause happens, the disease happens. [18]

\section{The HR Knowledge Exchange System and Expert Network as method of Healthy Organisation Model}

HR Knowledge Exchange System and Expert Network can be at the back of prevention, intervention, cure of organisational illnesses by supporting some organisational health criteria. HR Knowledge Exchange System and Expert Network can strengthen the belongingness, mattering, growth and development of the organisation, can influence positively the relationship of the organisation and its natural social and economical environment, and can enhance transparency.

\subsection{Strengthening Belongingness}

Members of the organisation need to feel they are part of the organisation and the togetherness. The Belongingness receives marked place among the healthy organisation's conditions [19]. HR professionals and their leaders are given even personalized support for their work by HR Knowledge Exchange System and Expert Network to increase their achievement and efficiency of their work. Moreover HR Knowledge Exchange System and Expert Network offers them belongingness and an online and offline HR social network. They can get some kind of power and impact both in HR Knowledge Exchange System and Expert Network (through sharing ideas and best practises and using them other HR professionals) and their own organisation (through import and applying of the new knowledge).

Everyone wants to feel that things depend on them in situations, so it is very important for people to have a sense of importance in all areas of society. People do not tolerate lack of importance, they also need the feeling that they do count at their working place, and their opinions matter. [19] 
Belongingness can be strengthened by HR Knowledge Exchange System and Expert Network through mattering. Also HR professionals and their leaders, members of Expert Network and Censorious Committee can feel mattering in this project. HR professionals and their leaders not only receive professional support from members of Expert Network, but also provide support to each other by sharing best practises and by applying new knowledge in their organisation and they may became important colleagues in their working place and in offline and online network. This allows them to be important members of both HR social network and their own organisation, additionally they can feel that they are beneficial part of public administration, because they effect on it with the new knowledge from the social network and from the experts. Experts can experience the fact that they are also important and respected members of the professional community network and may have an impact on organisations by providing personalized support to HR professionals and by creating publications. Mattering means for members of Censorious Committee, that they determine which knowledge can reach the target group by approving papers from Experts.

\subsection{Develepment of Hungarian Civil Service's personnel management}

One of the health criterias is that organisations grow and develop over time. Growth in Hungarian Civil Service is a state-defined factor, so this aspect is not being analysed in this article because the organisations themselves or the HR Knowledge Exchange System and Expert Network's tools and methods have no effect on this factor. On the other hand development is an important factor in Hungarian Civil Service, because if an organisation lacks the ambition to improve or find and test new opportunities and to learn, it will stagnate. Employees feel internal motivation to develop their skills and to be in more complex situations. If an organisation does not develop, then their co-workers cannot develop either, that is why they become frustrated and eventually leave the organisation. [19] HR Knowledge Exchange System and Expert Network also improve personal and organisational development. The knowledge of HR professionals and their leaders is growing, and the number of ideas and solutions increase at the HR departments of Hungarian Civil Service because of the facilitation of newly imported up-to-date HR Knowledge. HR professionals will not only be administrative workers, they can also expand their scope of activity through theoretical and practical knowledge from Experts and from the HR Knowledge repository portal. Hence HR Knowledge Exchange System and Expert Network offers tools and methods to Hungarian Civil Service's organisations to develop themselves.

\subsection{Enhancement of organisational brand in Hungarian Civil Service}

Further to not only the organisations - including Hungarian Civil Service's organisations - are largely defined by the society around them but also organisations have effect on society and can shape the views of people about Hungarian Civil Service. If organisations do not adapt to their environment such as live organisms they will die or become extinct. [19] Organisations in Hungarian Civil Service will not be extinct because the state ensures their survival, but they are competing with the other organisations on the job market for highly trained, talented workers have a positive opinion. Having a positive opinion on Hungarian Civil Service and governmental institutes is essential to provide specialist supplies for public sector.

That is why it is highly important to enhance the decreased social trust in the EU, caused by the economic crisis in the public sector organisations, to make the public sector become an attractive working place again for the employees. [17] 
HR Knowledge Exchange System and Expert Network can help the Hungarian Civil Service gain reputation among employees by having a professional support program for HR professionals. This program is modern, interactive, Internet-based and can keep Hungarian Civil Service up to date and provides new knowledge in an innovative way, and follow the expectation of 21th century. Besides it can create online and offline social network for HR professionals and their leaders, where they matter, develop themselves and the public sector so that makes positive opinion about Hungarian Civil Service and makes attractive workplace for jobseekers and colleagues.

Social trust and positive opinion can be further raised by transparency of HR departments of public administration through beginning of sharing best practises with each other. If an HR department has best practice, they can share it with other organisations. This sharing sets the new practical knowledge transparent and may make more efficient the tasks and processes in other organisations of Hungarian Civil Service, which can also lead to the impression of a modern and attractive workplace.

\subsection{Prevention, intervention of organisational illnesses}

You can see above that HR Knowledge Exchange System and Expert Network can have an impact on some of the organisational health criterias. The tools and methods used in the project can help to cure and prevent any organisational illness in the Hungarian Civil Service by affecting the following criterias of a healthy organisation:

HR Knowledge Exchange System and Expert Network meets the needs of internal customers (employees of Hungarian Civil Service) by providing great value to employees and leaders through the social network, new and summarized knowledge, organisational-fit solutions. HR professionals and their leaders can deliver these to all departments of institutions in the public sector, making the existence of HR department even more legitimate in the public sector.

The institutions of the public sector do not have economic requirements (eg. financial profit) because they are maintained by the Hungarian Government, so in this case the profit means the new knowledge, the good practices and the useful recommendations for internal colleagues of the Hungarian Civil Service's organisations.

The organisations in Hungarian Civil Service can satisfy the needs of its members through HR Knowledge Exchange System and Expert Network by creating an environment where members develop (grow) and believe that they matter, know that they are important so that they can achieve their individual goals while also achieving the organisation's aims. HR professionals and their leaders can fulfil this importance and development through up-to-date new knowledge, online and offline support from experts, knowledge sharing to each other, offline project related events and membership in online and offline HR social network. HR professionals and their leaders will also be able to create an environment for the other colleagues in the own organisations through the new knowledge provided by HR Knowledge Exchange System and Expert Network that will enable them to achieve their goals, develop and meet organisational aims, because HR professionals will not only be able to carry out administrative tasks. HR Knowledge Exchange System and Expert Network can therefore satisfy the needs of not only HR departments, but also indirectly of other employees of Hungarian Civil Service..

HR Knowledge Exchange System and Expert Network can contribute to the development of Hungarian Civil Service's organisations over time, increasing its ability to handle complex situations. The new, summarized HR methodological knowledge and best practices will be available equally to 
registered HR professionals and HR leaders. So the knowledge of the organisation will grow, Experts create professional organisation-fit solutions to the problems, the online and offline social network generate contact between organisations in public sector, all of these allows all employees of public sector to reach ability to handle complex situations.

With the support of HR Knowledge Exchange System and Expert Network organisations in Hungarian Civil Service can lives in harmony with its natural social environment, because HR Knowledge Exchange System and Expert Network provides up-to-date theoretical and practical knowledge to HR professionals and their leader in modern, Internet-based, interactive way, which adapt to 21 st century's expectation and environment, additionally open to technological processes of present days.

\section{Conclusion}

Digitalization and decentralization puts double pressure on public administration. It cannot pull itself out of any of them. In order to be able to adapt to them, place and role of personnel activity needs to be rethought in organisational development, and human resources processes of public sector must be radically redesigned. In this transformation, renewal of HR knowledge and sharing of knowledge contents has a central position. We tend to see more and more innovation initiatives in some countries, their common role is the improvement and distribution of new HR methods, techniques, processes. Hungary is also part of this process. The focus of the HR development of Hungarian public sector is creating and sharing professional, and methodological HR knowledge, and creating and HR community network.

\section{References}

[1] World Economic Forum, The Future of Jobs Report, 2018.

[2] NÉMETHY, A., (2018) A jövő munkahelyének HR igény változásai a robotizáció és a fenntartható fejlödés tükrében (Ph.D.). Szent István University, 2018.

[3] Une solution centrée sur l'employé et axée sur les compétences pour l'ensemble de vos cas d'usage. (2019). Retrieved 26 December 2019 from https://www.clustree.com/solution

[4] COURLAS, S., (2019) Retrieved 26 December 2019, from https://assets.kpmg/ content/dam/kpmg/ ca/pdf/2018/11/les-ressources-humaines-de-demain-2019.pdf

[5] KAJI, J., HURLEY, B., GANGOPADHYAY, N., BHAT, R. and KHAN, A., (2019) Global Human Capital Trends, 2019. Retrieved 26 December 2019, from https://www2.deloitte.com/us/en/insights/ focus/human-capital-trends.html

[6] Public Administration. (2017). A DIGITÁLIS JÓLÉT PROGRAM 2.0 Budapest.

[7] Public Services and Procurement Canada. (2020). Retrieved 5 January 2020, from https://www.tpsgc-pwgsc.gc.ca/comm/index-eng.html

[8] Werken voor Nederland is werken voor de Rijksoverheid - Werken voor Nederland. (2020). Retrieved 3 January 2020, from https://www.werkenvoornederland.nl/ 
[9] PHILIPPART, P., (2020) Werken aan de favoriete werkgever van Nederland. 2018. Retrieved 3 January 2020, from https://www.publiekperspectief.nl/werken-aan-favoriete-werkgevernederland/

[10] SOPER, D. and RICHARDSON, J., (2020) New applicant tracking system takes recruitment to a different level. 2019. Retrieved 3 January 2020, from https://civilservice.blog.gov. uk/2019/09/ 11/new-applicant-tracking-system-takes-recruitment-to-a-different- level/

[11] Jobbörse. (2020). Retrieved 5 January 2020, from http://www.jobboerse.gv.at/

[12] DUMOULIN, S., (2020)« Moncompteformation », une « appli » inspirée des géants de la tech. 2019. Retrieved 5 January 2020, from https:/www.lesechos.fr/economie- france/social/ moncompteformation-une-appli-inspiree-des-geants-de-la-tech-1133279

[13] Bundesverwaltung: Digitalisierungstarifvertrag für den öffentlichen Dienst geplant, https://oeffentlicher-dienst-news.de/bundesverwaltung-digitalisierungstarifvertragverdi-innenministerium-dbb-e-government/

[14] Telework.gov. (2020). Retrieved 5 January 2020, from https://www.telework.gov/

[15] \#GovLabLatvia - Latvijas valsts pārvaldes inovācijas laboratorijas. (2019). Retrieved 5 January 2020, from https://www.mk.gov.lv/lv/content/govlablatvia-latvijas-valsts-parvaldes-inovacijas -laboratorijas

[16] KISS, G., (2019) Közszolgálati életpályák jogi szabályozása (1st ed.) Budapest: Nordex Nonprofit Kft. - Dialóg Campus Kiadó, 2019.

[17] KÖFOP-2.1.5-VEKOP-16 A versenyképes közszolgálat személyzeti utánpótlásának stratégiai támogatása (2017) Megvalósíthatósági tanulmány

[18] LÖVEY, I., NADKARNI, M. S. and ERDÉLYI, E., The Joyful Organisation - understanding organisational health, diseases and joy. Response Books (2003), New Delhi

[19] LÖVEY, I. and NADKARNI, M., (2003) Az örömteli szervezet - SZERVEZETI EGÉSZSÉG, BETEGSÉG, ÖRÖM. HVG Könyvek kiadó 